Research Article

\title{
Species Diversity, Growth, Status, and Biovolume of Taia River Riparian Forest in Southern Sierra Leone: Implications for Community-Based Conservation
}

\author{
Moses Fayiah (D), ${ }^{1,2}$ Baimba F. Kallon, ${ }^{2}$ Shikui Dong, ${ }^{1}$ Mathew S. James, ${ }^{3}$ and Sanjay Singh ${ }^{4}$ \\ ${ }^{1}$ State Key Laboratory of Environmental Simulation and Pollution Control, School of Environment, Beijing Normal University, \\ Beijing 100875, China \\ ${ }^{2}$ Department of Forestry, School of Natural Resources Management, Njala University, Moyamba District, \\ Southern Province, Sierra Leone \\ ${ }^{3}$ Department of Biological Sciences, School of Environmental Sciences, Njala University, Moyamba District, \\ Southern Province, Sierra Leone \\ ${ }^{4}$ Biodiversity and Climate Change Division, Indian Council of Forestry Research and Education, Dehradun, India
}

Correspondence should be addressed to Moses Fayiah; moses.fayiah@yahoo.co.uk

Received 22 August 2019; Accepted 28 December 2019; Published 18 November 2020

Academic Editor: Qing-Lai Dang

Copyright (c) 2020 Moses Fayiah et al. This is an open access article distributed under the Creative Commons Attribution License, which permits unrestricted use, distribution, and reproduction in any medium, provided the original work is properly cited.

\begin{abstract}
Riparian forest inventory is essential in understanding the floristic biodiversity and provides necessary information on the growth trend and status of plant diversity along forest ecosystem, especially the riparian forests. This study was undertaken to assess the species diversity, growth status, and bio-volume of Taia riparian forest for community-based conservation intervention. In this study, we enumerated 602 individual trees, which comprised 49 species that belong to 37 genera in 25 families. In total, 14 rectangular plots of dimension $20 \times 50 \mathrm{~m}^{2}$ were demarcated. All trees species within the sampled plots having diameter at breast height $[\mathrm{Dbh}] \geq 7 \mathrm{~cm}$ were identified and height measured using the Haga altimeter, girth and measuring tape to determine the growth status. The result shows that $83 \%$ of the trees enumerated have [Dbh] that range from 7 to $30 \mathrm{~cm}$, whereas $17 \%$ had [Dbh] greater than $30 \mathrm{~cm}$. Funtumia africana and Trichilia heudelotii were the dominant species in almost all aspects in the study area. Meliaceae, Apocynaceae, and Mimosaceae were the dominant families with the highest species. The Shannon diversity index was 3.094, whereas the Simpson and Evenness diversity was 0.9303 and 0.4502 , respectively. Other diversity indices estimated were Margalef 7.544, Equitability 0.7949 , and Fisher_alpha 12.77. The overall biovolume was $283.05 \mathrm{~m},{ }^{3}$ with a total basal cover of $12.54 \mathrm{~m}^{2}$. Height and [Dbh] were not significantly correlated with the biovolume. Biotic pressure such as fuelwood collection, unsustainable charcoal production, pole harvesting, bushfires, and other traditional and cultural functions contributes greatly to the exploitation of the riparian forest. Therefore, urgent strategic conservation and protection measures should be adopted to prevent further degradation of forest ecosystems along river banks in the district and other ecologies in Sierra Leone.
\end{abstract}

\section{Introduction}

Sierra Leone (coordinates- $6^{\circ} 55^{\prime}-10^{\circ} 14^{\prime} \mathrm{N}$ and $10^{\circ} 14^{\prime}-13^{\circ} 17^{\prime} \mathrm{W}$ ) with a land area of $72,300 \mathrm{sq}$. $\mathrm{km}$ is situated on the West Coast of Africa along the East Atlantic Coast in Africa. The country's geographic location is a quintessential factor that determines the diversity of its ecosystems, vegetation, and biodiversity $[1,2]$. Sierra Leone is located within the Upper Guinean biodiversity hot spot of West Africa [1, 3-7]. There are five major terrestrial ecosystems in Sierra Leone, namely, (1) wetland and freshwater, (2) lowland rainforest, (3) coastal and marine, (4) montane forests, and (5) savanna woodlands [8]. Sierra Leone is endowed with nine major rivers. These rivers and their tributaries host long tracks of riparian forests along their banks with diverse plant and animal species. World Bank [1] report stated that the wetlands of Sierra Leone including riparian forests, mangroves, and swamps account for $4,800 \mathrm{~km}^{2}$ and are host to 
diverse biodiversity. According to Karim [9], riverine or riparian and gallery forests accounted for 35,870 ha, which is 0.5 of the country's total land area. However, based on FAO [10] report, about $12.6 \%$ of the estimated $38.1 \%$ forest area of Sierra Leone was lost between 1990 and 2010. In a nutshell, the country lost an average of 390, 00 ha of forest cover over this period at $0.63 \%$ per year. A recent FAO/FRA [11] report gave the annual forest change statistics of Sierra Leone from 1990 to 2015 as follows: $-4.4 \%$ 1990-2000, $-8.1 \%$ 2000-2010, $1.1 \% 1990-2015$, and $-4.8 \% 1990-2015$, respectively. However, Wadsworth and Lebbie [3] cautioned the accuracy and credibility of forest area figures given by FAO every five years. They argue that the classification system used by FAO and the data supplied by the country's authorities on forest cover of Sierra Leone are most times exaggerated and ambiguous.

Typical riparian forests are known to consist of freshwater swamp forests and are mostly found in lowland rainforest along with narrow water bodies. In these environments, the temperature is milder and the humidity is higher than the surrounding highlands. Rodrigues and Shepherd [12] noted that riparian forests are one of the biosphere's most complex ecological systems rich in biodiversity and essential for maintaining the vitality of the landscape and flow of rivers [13]. The riparian forests are essential for the protection of watersheds [1], and when they are destroyed, siltation and degradation of the watercourses become severe. Additionally, riparian zones form the interface between aquatic and terrestrial ecosystems and are often characterized by unique plant diversity with different ecosystem function as compared with surrounding communities [13]. The flora of these ecosystems provides essential ecosystem functions (e.g., stabilizing stream banks, controlling nutrients, and providing habitat) and services such as flood mitigation and groundwater recharge [14-16]. These forests also play a role in the mitigation and movement of many terrestrial animal species, forming corridors of connectivity between different forest patches [17]. Furthermore, humans, as well as aquatic biota and other animals, depend on these services for their well-being and as habitat [18]. They are a reservoir for wild plants and animals facing extinction in the typical forest as a result of urbanization and other biotic activities. Studies have also shown that riparian forests serve as corridors for maintaining regional biodiversity [19], providing vital links in the landscape for birds and small mammals [20-22]. Despite their size in patches, riparian forests are highly complex, diverse, and productive systems of significant ecological, social, and economic values [23-26].

Though the riparian forests along the Taia River are essential in protecting the river, however, little or less consideration has been attached to its conservation nor have any or regular scientific studies been conducted to assess its status and biodiversity in recent years. The Taia River and its riparian forest serve as a livelihood hub for most of the local residents along its path, thereby making it a focal point of conservation. Besides the direct ecosystem services such as nontimber forest products and other woody product functions of the Tai riparian forest, it provides aesthetic and recreational scenery, and adds value to the landscape. However, the degradation of riparian forests caused by agriculture and population settlements globally drives the loss of environmental quality in watersheds [27]. The alteration of the forest structure is brought about primarily through massive vegetal clearance for agriculture, charcoal production, and sand mining. Biswas and Mallik [28] noted that the disturbance intensity of riparian forests is likely to have direct effects on plant diversity and biovolume as a result of environmental changes, and this decreases the ecosystem habitat stability. Habitat destruction and degradation is the most potent threat to biodiversity in Sierra Leone and has been subjected to severe threats, both direct and indirect [2]. Many of these riparian forests in the world were spared in the past few decades from human destruction due to difficulty in accessing them and also to periodic flooding regimes [29].

Many researchers [30-41] have conducted various studies on riparian forest globally. Nevertheless, very little documentation is available for the riparian forests within Sierra Leone with Taia riparian forest in particular and even where was the said piece of information is available, it is unpublished and outdated.

In Sierra Leone, although few quantitative plant diversity studies are available, however, no comprehensive study on riparian forests has been done in recent years. Reference from $[2,3,42]$ confirmed that literature on plant diversity and forest cover is scarce and uncertain where available. As tree species diversity varies significantly from location to location due to the variations in biogeographic habitat and disturbance [43], it is essential for inventories to be conducted in riparian and all forest types to make available quantitative data on plant diversity, forest cover, structure, and composition of tree species in all forests in Sierra Leone. This work intends to give an insight into the plant diversity, growth status, and biovolume of riparian forests, with a focus on Taia riparian forests. Results from this study will provide useful insight into the ecological status and plant diversity of forests along river banks in Sierra Leone. Hence, the primary motive for undertaking this study is to provide adequate knowledge and bridge the riparian forests diversity status uncertainties gap that have existed over the past decades in Sierra Leone.

\section{Methodology}

2.1. Description of the Study Area. The study was conducted in a Riparian forest along the Taia River within Kori Chiefdom, Moyamba District, Southern Sierra Leone, with coordinates ranging from $\mathrm{N} 08^{\circ} 06^{\prime} 31^{\prime \prime} \mathrm{W} 012^{\circ} 05^{\prime} 00.2^{\prime \prime}$ to $\mathrm{N}$ $08^{\circ} 19^{\prime} 24.8^{\prime \prime} \mathrm{W} 012^{\circ} 10^{\prime} 28.1^{\prime \prime}$. The study area has two pronounce and distinct seasons. The rainy season starts mostly in May and ends in October, whereas the dry season starts in November and ends in April. The average annual rainfall ranges between 2000 and $3500 \mathrm{~mm}$. The maximum monthly mean temperature ranges between 21 and 23 degree Celsius for the substantial part of the day and night, most notably during the rainy season [44]. The study area is 
located approximately $150 \mathrm{~km}$ from the capital city, Freetown. Taia riparian forest is in close proximity to residential settlements, and the main occupation in this area is farming, fishing, pole harvesting, and charcoal production.

The clay classification in the study area is called the "Nyawama Series." The Nyawama soils make up an essential part of the nearly level ( 0 to 3 per cent slope) terraces along the meanders of Taia River. "Textures are sandy clay loam to clay loam in the topsoil, usually changing towards clay or sandy clay in the subsoil" [45].

2.2. Tree Species Identification. The botanical name of species, family, and genera of all the trees encountered in the sample plots was identified using flora of Sierra Leone by [46]. In cases where a tree's scientific name was not known immediately, such a tree was identified by its commercial or local name and representative parts of the tree collected and pressed for further identification at the National Herbarium at Njala University.

2.3. Study Design and Method. The study was carried out in June 2017. Fourteen (14) rectangular plots of dimension $20 \times 50 \mathrm{~m}$ were laid out within the study area. The systematic sampling design as per Mishra [47, 48] was used in conducting the field inventory. The [Dbh] of trees was recorded at $1.3 \mathrm{~m}$ breast height of trees in each plot. A tape rule was used to determine the directions of the perpendicular baselines and also the length of these lines of dimension $140 \mathrm{~m}$ and $100 \mathrm{~m}$, respectively. Along the $140 \mathrm{~m}$ line transect, a peg with a tag was placed at each 20-m distance, and a straight line was cut through to reach the $50 \mathrm{~m}$ dividing line to indicate one side of the $20 \times 50 \mathrm{~m}$ rectangular plot. Seven $20 \times 50-\mathrm{m}$ plots were laid out on either side of this dividing line. All trees within each plot with a $[\mathrm{Dbh}] \geq 7 \mathrm{~cm}$ were identified as per Mishra $[47,48]$, and their [Dbh] was measured using a girthing tape. The Spiegel Relascope was used to determine values of elevation and depression that were used to determine the height of each tree whose [Dbh] was measured.

2.3.1. Data Analysis. The relative density and dominance were obtained using the formula given by [45, 47] methods. The frequency and abundance of species were calculated using the standard methodology, as described by [47]. Basal area of all the trees was calculated as per [49].

Multidiversity indices were calculated by Shannon and Wiener [50], Kent and Coker [51], and Gaines et al. [52], and using Simpson diversity index by $[47,53,54]$. Species evenness $[E]$ was determined using Shannon's equitability $[\mathrm{EH}]$ as stated by $[49,51,55]$.
(1) Basal area calculation: the basal area of all trees was calculated using the formula $\mathrm{BA}=\pi D^{2} / 4$, where $\mathrm{BA}$ is the basal area $\left(\mathrm{m}^{2}\right), D$ is the diameter at breast height $(\mathrm{cm})$, and $\pi$ is pie [3.14].

(2) Biovolume calculation: the biovolume of individual trees was estimated using the equation developed for trees biovolume estimation in lowland rainforests [56]. The equation is expressed as follows:

$$
V=e-8.433 \pm 2.331 \operatorname{Ln}[D]
$$

where $V$ is the volume of a tree $\left(\mathrm{m}^{3}\right)$ and $D$ is Dbh $(\mathrm{cm})$.

(3) Shannon-Weiner diversity index $(H)$ : the Shannon-Wiener diversity index (Shannon and Wiener [50], Kent and Coker [51], and Gaines et al. [52]) was calculated using the formula:

$$
\text { SHDI }=-\sum_{i=1}^{S}\left(P_{i} \times \ln P_{i}\right),
$$

where $H 1$ is the Shannon-Wiener index of diversity, $P_{i}$ is the proportion of individuals of a species, $S$ is the number of species in the community, $\Sigma$ is the summation symbol, and $\ln$ is the natural logarithm to the base $e$.

(4) Simpson's Diversity Index (D): Simpson diversity was calculated by methods of $[47,53,54]$ :

$$
\text { SIDI }=1-\sum_{i=1}^{S} P_{i}^{2},
$$

where $D$ is the dominance of the index, $P_{i}$ is the proportion of the $i$ th species, and $S$ is the number of individuals of all the species.

(5) Species evenness: $[E]$ was determined using Shannon's equitability $[\mathrm{EH}]$ as stated by Kent and Coker [51]:

$$
J^{\prime}=\frac{H^{\prime}}{\log (S)}
$$

where $S$ represents the species total number in each community.

(6) Importance Value Index (IVI): importance value index $($ IVI $)=$ relative frequency + relative density + relative dominance. The percentage value of the relative frequency, relative density, and relative dominance is summed up together, and this value is designated as IVI of the species [47]. Species relative density and dominance were obtained using the formula given by $[45,47,48,57]$ methods: 
the density of a species $=\frac{\text { total number of individuals of species in all plots laid }}{\text { total area of the plot laid }}$

$$
\begin{aligned}
& \text { relative density of a species }=\frac{\text { density of a species }}{\text { density of all the plots }} \times 100, \\
& \text { dominance of a species }=\frac{\text { total basal area of each individual of a species in all plots laid }}{\text { total area of the plots laid }},
\end{aligned}
$$

relative dominance of a species $(\%)=\frac{\text { dominance of a species }}{\text { dominance of all the species }} \times 100$,

frequency of species $=\frac{\text { total number of quadrat of occurrence of species }}{\text { total number of plots laid }}$,

relative frequency of species $(\%)=\frac{\text { frequency of a species }}{\text { frequency of all the species }} \times 100$.

\section{Results}

3.1. Species Composition Assessment Parameters. The various species composition ecological parameters such as species diversity, richness, density, frequency, basal cover, dominance, importance value index, and other diversity indices were calculated for the study site (Table 1) Summary of all diversity indices is presented in Table 2.

3.2. Species Diversity and Richness. A total of 602 individuals [Dbh $\geq 7 \mathrm{~cm}]$ of 49 species from 37 genera and 25 families were recorded from the study area (Table 1). Funtumia africana and Trichilia heudelotii show dominance in almost all aspects of the study area. Meliaceae, Apocynaceae, and Mimosaceae are the dominant families with the highest individuals in the studied riparian forest ecosystem (Table 3). Combretaceae and Rhizophoraceae were the only two families that had only one member each in the entire study area. The Shannon diversity for the study area was 3.094, whereas the Simpson and evenness diversity was 0.9303 and 0.4502 , respectively. Other diversity indices values are recorded in Table 2.

3.3. Species Growth Parameters. About $83 \%$ of the trees documented had [Dbh] that ranges from 7 to $30 \mathrm{~cm}$, whereas $39 \%$ of the trees had [Dbh] ranges within 7-12 cm (Figure 1). The total basal area in the sample plots is $5,605 \mathrm{~m}^{2}$, whereas the mean basal area for the plots was $0.114 \mathrm{~m}^{2}$. The size class distribution [SCD] of individuals in the study area showed that most of the individual species [38.9\%] in the sampled community fall within $\geq 7-12 \mathrm{~cm}$ size class, whereas [20.76\%] fell in size class of $13-18 \mathrm{~cm}$ (Figure 2). Plot 13 recorded higher mean [Dbh] of $33.0 \mathrm{~cm}$, whereas plot 6 recorded the least of $14.5 \mathrm{~cm}$. The overall tree density for the study area was $414,29 \mathrm{Indi} / \mathrm{ha}$. The height class distribution of the site ranges from $5 \mathrm{~m}$ to $60 \mathrm{~m}$ (Figure 1 ). The overall biovolume for the study site was $283,05 \mathrm{~m}^{3}$, with a total basal cover of $12,54 \mathrm{~m}^{2}$ (Table 1 ). The cumulative regeneration status of the site is presented in Figure 3. The negative slope value [-1.943] of the SCD curve represents a fair regeneration in the riparian forest [58]. A positively weak relationship was seen to exit between height of trees and their diameter at breast height (Figure 4).

\section{Discussion}

Based on recent scientific evidence, it is hypothesized that riparian forests are rich in biodiversity due to their proximity to constant water supply [59]. Riparian forests that are sustainably managed have the ability to provide water support throughout the season in an adequate quantity. Gomez-Roxas et al. [60] stated that herbaceous woody plant has the ability to slow and check floodwater flow rate and at the same time protects soil from being eroded by the water force. The Taia riparian forest is moderately diverse when compared with recent species composition studies carried out in the country in different ecological zones [2]. The findings of the study reveal that though Taia Riparian forest is under massive pressure from the surrounding communities for services such as fuelwood and charcoal production, however, the forest shows signs of resilience and the potential of maintaining rich biodiversity if protection or conservation methods are instituted (Figure 5). The results of this finding, however, disagree with the conclusions made by $[23,61]$ that riparian forest demonstrates a high level of biodiversity. Across the West African region, for example, Sambaré et al. [26] recorded a total of 196 species representing 139 genera and 51 families in riparian forests within Burkina Faso. Additionally, Natta et al. [23] in Benin republic recorded 1,002 species (about $1 / 3$ of the estimated Benin flora from 120 families and 515 genera in 19 ha with the most species-rich families being Leguminosae, Poaceae, Rubiaceae, Euphorbiaceae, Cyperaceae, Asteraceae, and Acanthaceae, respectively). Similarly, Pereki et al. [62] in 
TABLE 1: Species composition parameters and biovolume.

\begin{tabular}{|c|c|c|c|c|c|c|c|c|c|c|c|c|c|c|}
\hline Trees species & Indiv & PltsO & $\mathrm{A}, \mathrm{Db}$ & Av ht & $\mathrm{ABA}$ & Dom & D (ha) & Freq & $\mathrm{BC}(\mathrm{h})$ & Rden & $\mathrm{RF}$ & Rdom & IVI & Bio-V \\
\hline Trichilie heudelotii & 94 & 9 & 12.9 & 10.4 & 0.01 & 10.44 & 67.14 & 64.29 & 0.88 & 16.21 & 7.03 & 7.00 & 30.24 & 9.12 \\
\hline Funtumia africana & 70 & 10 & 12.2 & 11.2 & 0.01 & 7.00 & 50.00 & & 0.58 & 12.07 & 7.81 & 4.66 & 24.54 & 6.54 \\
\hline Myrianthus arboreus & 43 & 8 & 11.0 & 9.9 & 0.01 & 5.38 & 30.71 & 57.14 & 0.29 & 7.41 & 6.25 & 2.33 & & 2.89 \\
\hline leasa lanceolate & 41 & 6 & 13.0 & 14.9 & 0.01 & & & & & & & & & 5.79 \\
\hline Albizia zygia & 36 & 7 & 11.4 & 13.7 & 0.01 & 5.14 & 25.71 & 50.00 & 0.26 & 6.21 & 5.47 & 2.09 & 13.77 & 3.59 \\
\hline Pynanthus angolensis & 31 & 4 & 13.6 & 18.3 & 0.01 & 7.75 & 22.14 & 28.57 & 0.32 & 5.34 & 3.13 & 2.56 & 11.03 & 5.88 \\
\hline Cola gigantean & 30 & 7 & 10.5 & 14.4 & 0.01 & 4.29 & & 50.00 & & 5.17 & 5.47 & 1.48 & & 2.67 \\
\hline Synsealus brevepics & 28 & 6 & 16.1 & 13.4 & 0.02 & 4.67 & 20.00 & 42.86 & & 4.83 & 4.69 & 3.25 & 12.76 & 5.45 \\
\hline Diealiun pobeguinii & 25 & 5 & 15.3 & 15.8 & 0.02 & 5.00 & 17.86 & 35.71 & & 4.31 & 3.91 & 2.62 & 10.83 & 5.18 \\
\hline Pterocarpus santaliniodes & 22 & 4 & 18.4 & 22.2 & 0.03 & 5.50 & 15.71 & 28.57 & 0.42 & 3.79 & 3.13 & 3.33 & 10.25 & 9.27 \\
\hline Milicia regia & 13 & 3 & 17.9 & 13.9 & 0.03 & 4.33 & 9.29 & 21.43 & 0.2 & 2.24 & 2.34 & 1.86 & 6.45 & 3.25 \\
\hline Chassalia carollifere & 13 & 4 & & 9.4 & 0.03 & & & 28.57 & 0.26 & 2.24 & & 2.08 & 7. & 2.45 \\
\hline as mombin & 11 & 2 & & 19.6 & 0.02 & & & & & 1.90 & & 1.42 & & 3.49 \\
\hline Cheistopholis patens & 9 & 2 & 16.8 & 19.0 & 0.02 & 4.50 & & & & 1.55 & 1.56 & 1.14 & 4.25 & 2.71 \\
\hline Ochthocosmus africanus & 9 & 3 & 21.4 & 24.0 & 0.04 & 3.00 & 6.43 & 21.43 & 0.23 & 1.55 & 2.34 & 1.84 & 5.74 & 5.55 \\
\hline Dryptes aubrevillei & 9 & 3 & 23.4 & 16.3 & 0.04 & 3.00 & & & & 1.55 & 2.34 & & & 4.50 \\
\hline Ficus & 9 & 2 & 49.0 & 31.8 & 0.19 & & & & & & & & & 38.53 \\
\hline atyfolis & 8 & 2 & 23.2 & 17.1 & 0.04 & 4.00 & & & & 1.38 & 1.56 & & & 4.13 \\
\hline$n$ sis & 7 & 2 & 19.4 & 32.1 & 0.03 & 3.50 & 5.00 & 14.29 & 0.1 & 1.21 & 1.56 & & 5 & 4.74 \\
\hline rginea & 6 & 1 & 24.1 & 23.2 & 0.05 & 6.00 & & & & 1.03 & 0. & & & 4.53 \\
\hline Ficus & 6 & 2 & & & & & & & & & & & & 2.29 \\
\hline thyrsa & 5 & 2 & 23.4 & 19.0 & 0.04 & 2.50 & & & & 0.8 & & & & 2.92 \\
\hline Cola & 5 & 2 & 26.3 & 17.3 & 0.05 & 2.50 & & 14.29 & 0. & 0.86 & 1. & & 7 & 3.35 \\
\hline Diace & 4 & 1 & 27.4 & 24.2 & 0.06 & 4.00 & 2.8 & 7.1 & 0. & 0.69 & 0. & 1. & 1 & 4.07 \\
\hline acantha & 4 & 3 & & & & & & & & & & & & \\
\hline ana & 4 & 2 & & & & & & & & & & & & 6.01 \\
\hline thifolia & 3 & 1 & 33.2 & 38.0 & 0.09 & 3.00 & 2.14 & 7.14 & 9 & 0.52 & 0.78 & 1. & 2. & 7.05 \\
\hline iweinfurthii & 3 & 1 & 20.1 & 20.1 & 0.03 & 3.00 & & & 0.0 & 0.52 & 0.7 & 0.5 & 4 & 1.37 \\
\hline liotii & 2 & 1 & 36.2 & 25.8 & 0.10 & & & & & & & & & 3.79 \\
\hline nurifola & 2 & 2 & & & & & & & & & & & & \\
\hline ricana & 2 & 1 & 29.6 & 32.5 & 0.07 & 2.00 & 1.43 & 7.14 & 0.1 & 0.34 & 0.78 & & 1 & 3.19 \\
\hline liotii & 2 & 1 & 41.4 & 31.0 & 0.13 & 2.00 & & & & 0.34 & 0.7 & & & 5.96 \\
\hline strum africanum & 2 & 1 & 45.2 & 31.2 & 0.16 & & & & & & 0. & & & 7.15 \\
\hline & 2 & 1 & & & & & & & & & & & & 2.84 \\
\hline atasi & 2 & 1 & 31.3 & 32.1 & 0.08 & 2.00 & & & 0.1 & 0.34 & 0.78 & & 2. & 3.53 \\
\hline & 2 & 1 & & 36.0 & 0.07 & 2.00 & & & & & 0.78 & & & 3.51 \\
\hline & 2 & 2 & & 23.9 & 0.09 & & & & & & 1. & & & 3.12 \\
\hline bonesis & 2 & 1 & & & 0.1 & & & & & & 0.7 & 2. & & 3.87 \\
\hline Trichilia lantana & 2 & 2 & 31.5 & 19.2 & 0.08 & 1.00 & 1.43 & 14.29 & 0.11 & 0.34 & 1.56 & 0.89 & 2.80 & 2.14 \\
\hline eudelotii & 1 & 1 & 17.0 & 22.0 & 0.02 & 1.00 & 0.71 & & 0.02 & 0.17 & 0.78 & 0.13 & 1.08 & 0.36 \\
\hline & 1 & 1 & 47.6 & 12.0 & 0.18 & 1.00 & & & & 0.17 & 0.78 & & 1.97 & 1.52 \\
\hline a ivorensis & 1 & 1 & 53.4 & 52.1 & 0.22 & 1.00 & 0.71 & & 0 . & & 0.7 & 1.2 & 2. & 8.33 \\
\hline Anicoshulla lauring & 1 & 1 & 50.7 & 27.2 & 0.20 & 1.00 & 0.71 & 7.14 & & & 0.78 & 1.15 & & 3.92 \\
\hline Inthocleista nobilis & 1 & 1 & 63.1 & 11.3 & 0.31 & 1.00 & 0.71 & 7.14 & 0.22 & 0.17 & 0.78 & 1.78 & 2.73 & 2.52 \\
\hline rdifolia & 1 & 1 & 74.3 & 12.4 & 0.43 & 1.00 & 0.71 & 7.14 & 0.31 & 0.17 & 0.78 & 2.47 & 3.42 & 3.84 \\
\hline Arthrocapus spp & 1 & 1 & 91.1 & 51.6 & 0.65 & 1.00 & 0.71 & 7.14 & 0.47 & 0.17 & 0.78 & 3.71 & 4.67 & 24.01 \\
\hline Dracaena alliotii & 1 & 1 & 95.8 & 39.2 & 0.72 & 1.00 & 0.71 & 7.14 & 0.51 & 0.17 & 0.78 & 4.11 & 5.06 & 20.17 \\
\hline Dracaena heudelotii & 1 & 1 & 87.2 & 33.9 & 0.60 & 1.00 & 0.71 & 7.14 & 0.43 & 0.17 & 0.78 & 3.40 & 4.35 & 14.45 \\
\hline Octhococosmos africanus & 1 & 1 & 21.5 & 18.7 & 0.04 & 1.00 & 0.71 & 7.14 & 0.03 & 0.17 & 0.78 & 0.21 & 1.16 & 0.48 \\
\hline Total & 602 & 14 & & & & & 414.29 & 914.29 & 12.54 & 100.00 & 100.0 & 100.00 & 300.00 & 283.05 \\
\hline
\end{tabular}

Note. Indiv means individual trees; $\mathrm{Plt}, \mathrm{O}=$ plots of occurrence; $\mathrm{A}, \mathrm{Db}=$ average diameter at breast height; $\mathrm{Av}$, ht $=$ average height; $\mathrm{ABA}=$ average basal area $\left(\mathrm{m}^{2}\right)$; Dorm $=$ dominance; BC $(\mathrm{h})=$ basal cover $\left(\mathrm{m}^{2}\right)$; Freq = frequency (percentage); D $(\mathrm{h})=$ density (individuals per ha); Rden = relative density; Rdom = relative dominance; $R F=$ relative frequency; $I V I=$ importance value index; Bio = bio-volume $\left(\mathrm{m}^{3}\right)$.

Togo also recorded a total of 258 plant species belonging to 119 genera from 63 families in Abdoulaye Wildlife Reserve dry forests. In East Africa, Mligo [59] in Tanzania reported a total of 261 plant species from 68 families in the Wami River system with a Shannon diversity index in the range of 1.63-2.94. The dominant plant families recorded were
Meliaceae, Apocynaceae, and Mimosaceae. Trichilia heudelotii from the Meliaceae family recorded the highest number of the individual followed by Rauvolfia vomitoria from the Apocynaceae family and Fucus mucosa from the Moraceae family. The abundance of these species in the study area is believed to be attributed to their strong 
TABLE 2: Summary of multidiversity indices of all quantifiable parameters.

\begin{tabular}{lccc}
\hline Diversity indices & Values of indices & Lower & Upper \\
\hline Taxa_S & 49 & 41 & 49 \\
Individuals & 602 & 602 & 602 \\
Dominance_D & 0.06972 & 0.06318 & 0.08067 \\
Simpson_1-D & 0.9303 & 0.9193 & 0.9368 \\
Shannon_H & 3.094 & 2.959 & 3.144 \\
Evenness_eH/S & 0.4502 & 0.4286 & 0.5169 \\
Brillouin & 2.954 & 2.834 & 3.006 \\
Menhinick & 2.035 & 1.702 & 2.035 \\
Margalef & 7.544 & 6.286 & 7.544 \\
Equitability_J & 0.7949 & 0.7792 & 0.8248 \\
\hline
\end{tabular}

TABLE 3: Numbers of individual species collected, their plant families, and botanical names.

\begin{tabular}{|c|c|c|c|c|}
\hline Family & Genera & Scientific name & Individual trees & Species per family \\
\hline Anacardiaceae & 1 & Spondias mombin & 11 & 1 \\
\hline Mimosaceae & 2 & $\begin{array}{c}\text { Albizia, Ferruginea } \\
\text { Albezia zygia } \\
\text { Albezia adianthifolia } \\
\text { Piptadensiastrum Africanum }\end{array}$ & 47 & 4 \\
\hline Meliaceae & 1 & $\begin{array}{c}\text { Trichilia, Heudilotii } \\
\text { Trichilia lantana } \\
\end{array}$ & 96 & 2 \\
\hline Caesalpiniaceae & 3 & $\begin{array}{l}\text { Afzelia Africana } \\
\text { Dialum, Pubeguinii } \\
\text { Dialim guineasis } \\
\text { Cassiavsieberia }\end{array}$ & 38 & 4 \\
\hline Apocyanaceae & 3 & $\begin{array}{l}\text { Rauvolfia vomitoria } \\
\text { Funtumia Africana } \\
\text { Alstonia boonei }\end{array}$ & 72 & 3 \\
\hline Sapotaceae & 1 & Synsepalous brevepis & 28 & 1 \\
\hline Annonaceae & 2 & $\begin{array}{l}\text { Cleistopholis patens } \\
\text { Xylopia aethiopica } \\
\text { Xylopia quintasii }\end{array}$ & 12 & 3 \\
\hline Boraginaceae & 1 & $\begin{array}{l}\text { Cardia platythyrsa } \\
\text { Cardia platyfolis }\end{array}$ & 14 & 2 \\
\hline Moraceae & 3 & $\begin{array}{c}\text { Ficus mucoso } \\
\text { Ficus vogelii } \\
\text { Melicia regia } \\
\text { Merianthus arboreus }\end{array}$ & 71 & 4 \\
\hline Ixonanthaceae & 1 & Octhocosmos africanus & 9 & 1 \\
\hline Ebanaceae & 1 & $\begin{array}{c}\text { Dyospyros eloitii } \\
\text { Dyrospyros heudelotii }\end{array}$ & 3 & 2 \\
\hline Myristicaceae & 1 & Pycnanthus angolensis & 31 & 1 \\
\hline Loganiaceae & 1 & $\begin{array}{c}\text { Anthocleista vogelii } \\
\text { Antholeista djaloneasis }\end{array}$ & 4 & 2 \\
\hline Myrsinaceae & 1 & Maesa lanceolata & 41 & 1 \\
\hline Dracaenaceae & 1 & $\begin{array}{l}\text { Dracaena alliotii } \\
\text { Dracaena ovate } \\
\text { Dracaena fragans } \\
\text { Dracaena heudelotii }\end{array}$ & 9 & 4 \\
\hline Bombacaceae & 1 & Ceiba pentandra & 8 & 1 \\
\hline Burseraceae & 1 & Canarium schweinfurthii & 3 & 1 \\
\hline Rubiaceae & 1 & Chassalia carolifera & 13 & 1 \\
\hline Papilionaceae & 1 & Pterocarpus santalinoides & 23 & 1 \\
\hline
\end{tabular}


TABle 3: Continued.

\begin{tabular}{|c|c|c|c|c|}
\hline Family & Genera & Scientific name & Individual trees & Species per family \\
\hline Sterculiaceae & 2 & $\begin{array}{c}\text { Cola lateritia } \\
\text { Cola gigantean } \\
\text { Sterculia trigacantha }\end{array}$ & 39 & 3 \\
\hline Euphorbiaceae & 2 & $\begin{array}{l}\text { Drypetes aubrevillei } \\
\text { Macaranga hurifolia }\end{array}$ & 11 & 2 \\
\hline Rosaceae & 1 & Parinari excelsa & 2 & 1 \\
\hline Irvingiaceae & 1 & Klainedoxe gabonensis & 2 & 1 \\
\hline Combretaceae & 1 & Terminalia ivorensis & 1 & 1 \\
\hline Rhizophoraceae & 1 & Anisophyllea laurina & 1 & 1 \\
\hline 25 & 37 & 49 & 602 & 49 \\
\hline
\end{tabular}

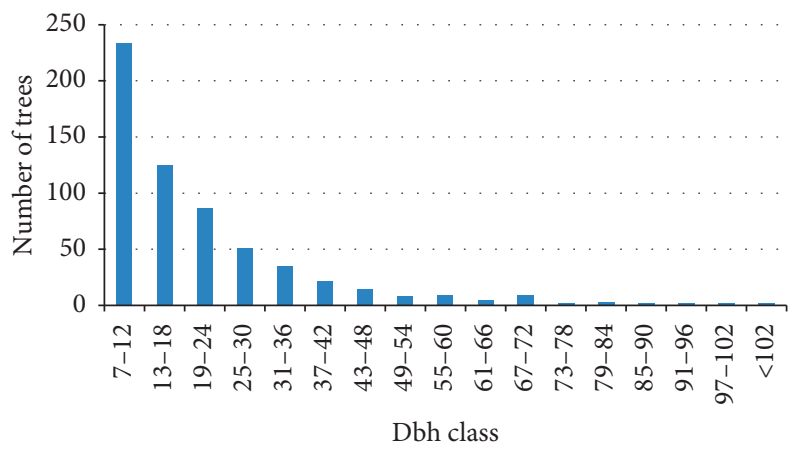

FIGURE 1: Dbh class distribution of trees.

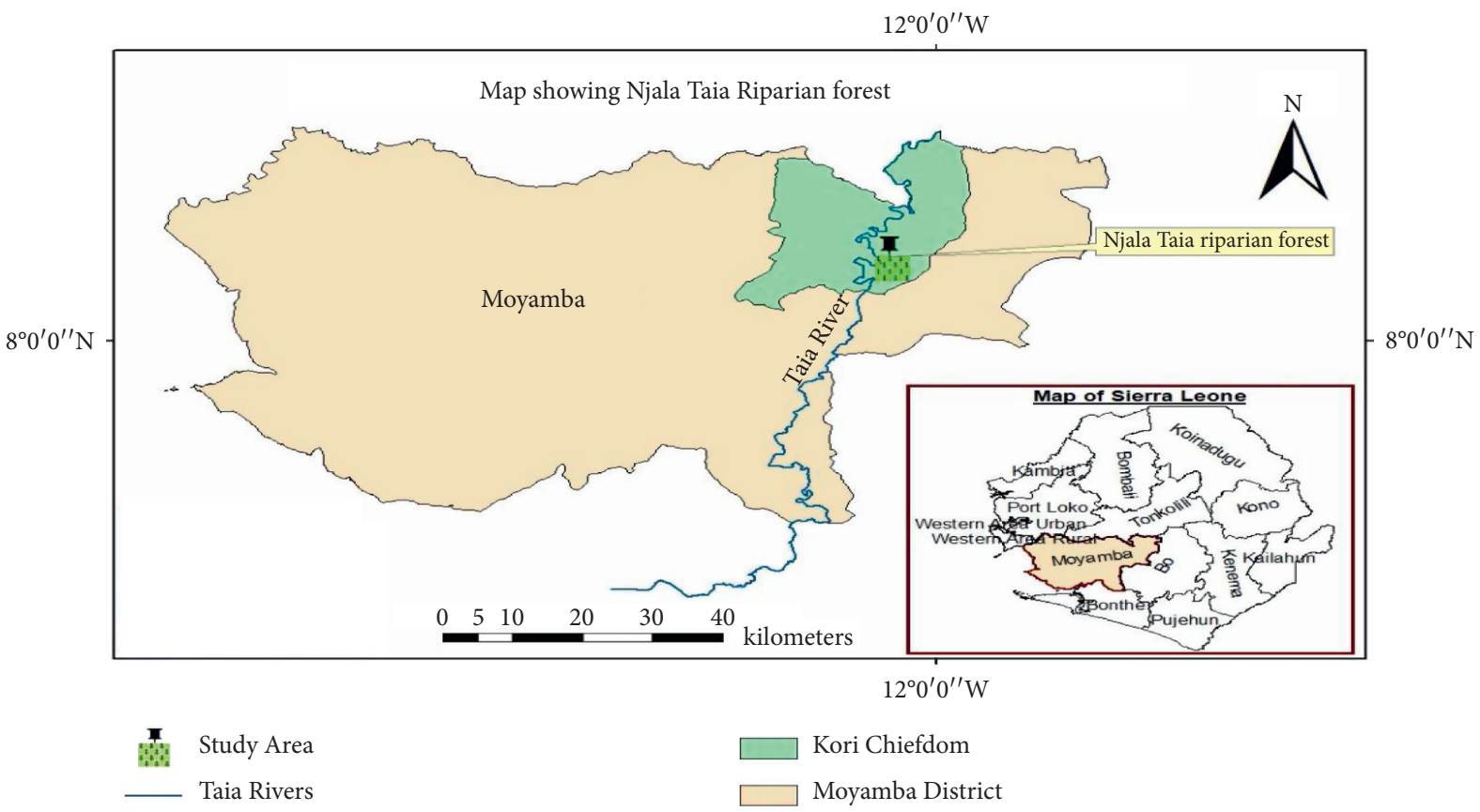

Figure 2: Map showing Taia River and its Riparian Forest.

adaptability characteristic as well as their lesser ability to be utilized as firewood, charcoal, pole, or timber. Appiah [63] and Rad et al. [64], however, warn that diversity is on the decrease when few species dominate an area. It is most likely that the edaphic condition of the study area is more favorable for certain species than the rest of the species. In other forest ecosystems in West Africa, Fabaceae, Meliaceae, Rubiaceae, Sterculiaceae, Euphorbiaceae, Combretaceae, Mimosaceae, Ebenaceae, Moraceae, and Bombacaceae were recorded as the most dominant plant families in Burkina 


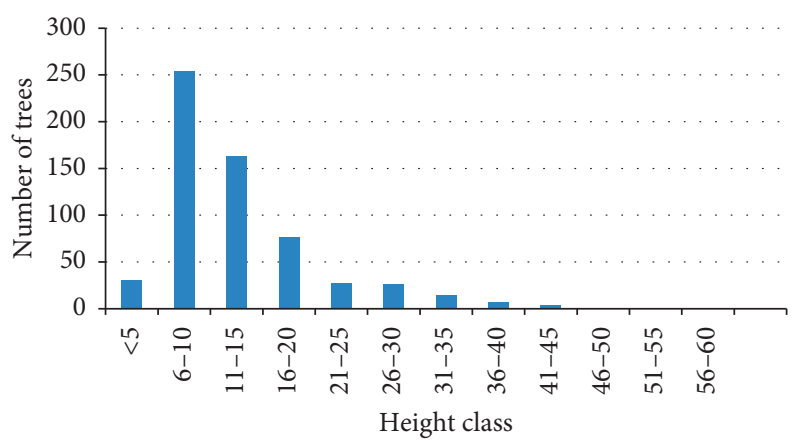

FIgURE 3: Height class distribution of trees.

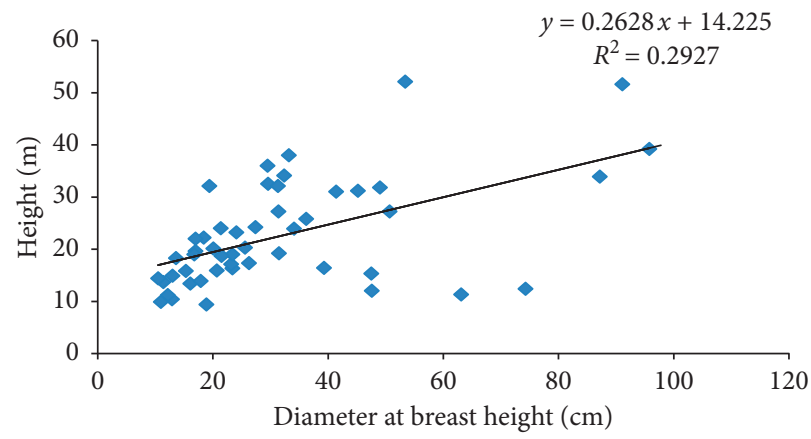

FIGURE 4: Relationship between height and diameter at breast height.

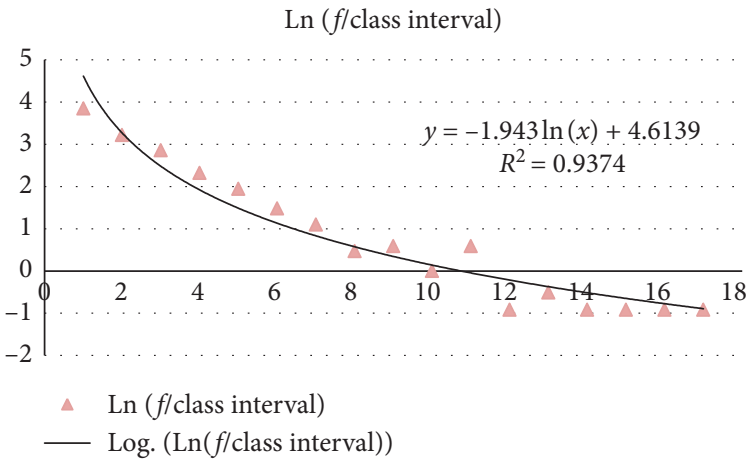

FIGURE 5: SCD curve showing regeneration status based on the log of frequency over a class interval. $\operatorname{Ln}=\log ; F=$ frequency.

Faso [26], whereas Anogeissus. leiocarpa, Pouteria. Alnifoliavar, alnifolia, Spondias mombin, Pterocarpus erinaceus, and C. giganteava were the most dominant plant species recorded in Togo [62]. Reynal-Roques [65] acknowledges that these families and their respective species are common in most tropical rain forest regions around the world.

The rationale for the differences plant diversity across the different riparian forests in West Africa could be attributed to anthropogenic activities such as logging, pole harvesting, fuelwood and charcoal production, wildfires, and proximity to settlement [1]. Across Africa, in general, biodiversity is under severe threats with very little being done in some countries to mitigate the situation [59]. When the demand for forest ecosystem services supersedes its carrying capacity because of intensive biotic disturbance and the collection of nontimber products, its biodiversity will decline at a rate faster than it can regenerate. According to Houehanou et al. [66], bushfires have proven to have adverse effects on trees species and hence affecting its density, especially in lower regions. Additionally, Pereki et al. [62] stated that social pressure open gap in the forest canopies through tree cutting or logging, and this may expose the lower layer to fire and other threats.

Shannon index of diversity is an information index; it confounds two components of diversity, species richness, and evenness [54]. The diversity value in the current study was recorded to be 3.094 , which is similar to (3.2) the value recorded by Fayiah et al. [42]. The Shannon Wiener value of 
Taia riparian forest is within the suggested or expected range as stated by [54], which is 1.5 and 3.5 as it rarely goes above 5.0. Compared with the Simpson index for diversity, the Shannon-Wiener diversity index indicates the diversity of species in the community. The recorded value is a clear indication of the diversity potential of the Taia riparian forest; hence, if conservation measures are put in place, natural regeneration is a possibility. Additionally, the Simpson and evenness values of $(0,9)$ is encouraging for a forest close to settlements like Taia riparian forests. Though from different ecologies, the Shannon diversity values within forests in the West African subregion as seen in [67] for Afi River Forest Reserve and Oban Forest Reserve (Nigeria) were 3.827 and 3.795 and it is a signal of diversity resilience in these ecosystems. Elsewhere, Sahoo et al. [68] also recorded higher Shannon and Simpson diversity index of 3.66 and 0.10, respectively, in Odisha, India. The size and forest conservation policies of India are believed to be far effective than those of other countries in the sub-African region; hence, higher diversity is expected.

\subsection{Comparing the Riparian Diversity and Other Ecosystems in} Sierra Leone. The ecological landscape of Sierra Leone is diverse with unique flora biodiversity across different ecosystems [1]. A recent study conducted in Kambui forest in the Eastern part of Sierra Leone by Fayiah et al. [42] recorded 36 trees species, 22 families from 122 individual trees within an area of 1.0 ha. Based on species richness and abundance, Taia riparian forest is slightly more biologically diverse than the Kambui forest. This could be attributed to many biotic and abiotic factors in play along the different ecologies. Similarly, weak forest protection policies are paving ways for more forest exploitation across Sierra Leone with Taia riparian forest not being an exception. Contrastingly, a study conducted a decade ago by Kargbo [69] recorded 132 plant families within an area of 1.01 ha in the same Kambui forest. Alternately, Bangura [70] reported (58) plant families from 1150 individual trees in an area of 1.40 ha in the Singamba forest reserve within Moyamba District, Southern Sierra Leone. However, it is not clear if the Singamba forest reserve still maintains such diversity over the years due to the trend of deforestation in the country. Although the forests ecosystem of the study area differs from other forests ecosystems, mentioned above, the climate, soil type, anthropogenic pattern, and demands from surrounding communities are more or less the same. The occurrence of diverse species within the same district and other parts of the country depicts unique flora biodiversity and terrestrial ecosystems. Fayiah et al. [42] suggested that high rainfall potential, sunlight, soil type, anthropogenic actions, and topography could be the cause of variation in flora diversity in different ecologies in Sierra Leone. Exceptionally, Gola forest reserve is the only remaining and adequately protected natural forest in Sierra Leone with rich biodiversity.

4.2. Growth Assessment Parameters. The diameter at breast height and a total height of trees are critical parameters in assessing the growth of vegetation [71], and they help us understand the trend of forest development. Size class distribution has been long used to study forest dynamics, changes in species composition, and regeneration [72]. From our results, it could be seen that the riparian forest is made up of mostly poles and sapling species in nature (Figures 1-3). There is a significantly weak relationship between height and diameter of trees species recorded in the study area (Figure 4). This implies that, as the height increases, the diameter at breast height also increases. Similarly, the biovolume values estimated depict that the forest is depleted and the current vegetation is young, with majority plant species being categorized as poles. In comparison, Fayiah et al. [42] recorded a volume of $391.78 \mathrm{~m}^{3}$ in Kambui Forest Reserve as compared with $284.0 \mathrm{~m}^{3}$ (Table 1) in this study. Soares et al. [73] and Moores et al. [74] stated that for the sustainable utilization of available forest resources, the volume is essential information. Additionally, Diamantopoulou [75] ascertain that volume is the most used measure of wood quantity to satisfy man's financial desire. The [Dbh] decrease, as seen in (Figure 1), automatically affected the total biovolume of the study area. Also, it is believed that species abundance and diversity directly have links with the biovolume, and thus sound restoration and community conservation projects will improve both the biovolume and species abundance of riparian forests. Characterization of SCD serves and is a means of projecting population trends and to some extent past trends [76], and its interpretation has been useful in assessing the state of the population for management purpose [77-81]. The negative slope value for the SCD curve indicates that there are more individuals in the lower size class, and thus the forest in the riparian zone of Taia River is regenerating successfully (Figure 5). However, the height and diameter values are good indicators for the classification of forest types in any given ecosystem. The SCD curve slope shows that more plant species fell in the sapling or pole category, indicating that tree species in the study area are smaller [Dbh] in size. The absence of larger big trees implies that logging is not taking place in this forest due to tree sizes.

4.3. The Impacts of Human Activities on Taia and Other Riparian Forests in Sierra Leone. Riparian forests render great support to rural livelihood in the form of wood energy, medicines, poles, and other nontimber forest products $[82,83]$. Based on these ecosystem services derived, its exploitation has skyrocketed, especially in Sierra Leone. NBSAP [1] report stated that biodiversity loss in Sierra Leone is mostly attributed to deforestation drivers such as poor mining practices and farming, bushfires, overgrazing, lack of resources and poverty, population pressure $[1,4]$, inappropriate policies, institutional weakness, and socioeconomic factors. However, these anthropogenic disturbance factors are not consistent across regions or ecosystem [84] in Sierra Leone. On the contrary, Martín et al. [85] highlighted factors such as road construction, dumping of solid and industrial waste, agricultural expansion, and modification of fluvial terraces were some of the factors that led to the deterioration of the riparian forests. Factors such as topography, settlement 
proximity, soil type, weak forest policies, and primitive shifting cultivation methods are the primary culprit of forest resources exploitation in the study area. Generally, the natural nature and ability of Taia riparian forests to maintain its vegetation in both seasons attracts roaming animals browsing, stimulate poles harvesting, and fuelwood and charcoal burning across the forest. According to a research done by Fayiah et al. [86], Spratt et al. [4], and USDA Forest Service [87], approximately more than $80 \%$ of Sierra Leone's population depend on fuelwood and charcoal for daily household energy. The high demand of forest resources for daily energy needs has placed huge pressure on forest across Sierra Leone and has resulted in forest reserve exploitation nationwide. The level of exploitation of the Taia riparian forest is believed to have a direct link with trees diameter size and height of trees enumerated in this study. The lower number of trees in higher size class (Figure 1) indicates that Taia riparian forest is undergoing exploitation constantly. However, favorable soil nutrients and moisture conditions within the forests provided by the riparian zone and aided with seed dispersal through the water-body support high regeneration in the study area (Figure 3). With proper protection and awareness about sustainable utilization of the wood resources, the diversity of the forest can be restored.

Alternately, the increase in the density of trees is strongly believed to be connected with the proximity of Taia riparian forests to the stream, canopy pattern, and temperature of the immediate environment. Scientific evidence has proven that the diversity of species is mostly dependent on community stability, interference level, and adaptability potential of the species [60]. Settlement proximity, socioeconomic status, and occupation of nearby indigenes play a crucial role in the exploitation of the Taia riparian forests. Typically, riparian forests are smaller in size, but their ecological, economic benefits are enormous to local indigenes [41]. Natta et al. [88] noted that resources availability in riparian forests for utilization by neighboring inhabitants must satisfy their basic needs and serve as a source of income as well. The absence of community forest protection by-law within the Kori Chiefdom contributes to more biotic pressure on the forests.

\section{Conclusion}

Decades of intense biotic activity couple with weak community forest protection by-laws has contributed to the loss of Sierra Leone forest estates, especially the riparian forests. The plant diversity of Taia riparian forest is moderate, with the majority of the stems being the size of poles and saplings. The sizes of plant species resulted in to the low biovolume and hence the need for strategic management and conservation approaches. The height and [Dbh] values recorded indicate that the riparian forest is immature and is under enormous pressure and needs urgent conservation attention. Although the diversity of species does not necessarily pose immediate threats of extinction now, they certainly possess long-term decline threats, especially if the riparian forests are continued to be altered at a rate faster than they can recover. It was however observed that the forests have good regeneration potential due to the climatic pattern and abundant soil water content in the study area. The assessment of species composition, growth, and biovolume of Taia riparian forest highlight the importance of communitybased conservation policies and serve as a baseline for future assessment of riparian forest ecosystems in Sierra Leone. For a continuous supply of essential ecosystem services, different stalk holders and nongovernmental organizations concern with environmental management and biodiversity conservation should partner with local indigenes. Based on the findings of this study, if appropriate conservation measures are not instituted urgently, Taia Riparian forest maybe at the verge of being reduced to a farm bush as a result of poles, fuelwood, and nonwood forest products collection. Additionally, charcoal burning has emerged as a big threat to vegetation growth and has reduced catchment areas along streams in Kori Chiefdom. Therefore, urgent strategic conservation and protection measures should be adopted to prevent further degradation of forest ecosystems along river banks in the district and other ecologies in Sierra Leone.

\section{Data Availability}

Data for this article will be made available upon request.

\section{Conflicts of Interest}

The authors declare that they have no conflicts of interest.

\section{Acknowledgments}

This research was financially supported by the grants from the Second Tibetan Plateau Scientific Expedition and Research Program (2019QZKK0307), National Key R\&D Program of China (2016YFC0501906), Qinghai Provincial Key R\&D Program (2019-SF-145 and 2018-NK-A2), and Qinghai Innovation Platform Construction Project (2017ZJ-Y20).

\section{References}

[1] N. Weber, R. Wistuba, J. Astrin, and J. Decher, "New records of bats and terrestrial small mammals from the Seli River in Sierra Leone before the construction of a hydroelectric dam," Biodiversity Data Journal, vol. 7, Article ID e34754, 2019.

[2] NBSAP, Sierra Leone's Second National Biodiversity Strategy and Action Plan (NBSAP) 2017-2026, Government of Sierra Leone through the Environment Protection Agency, Sierra Leone, West Africa, 2017.

[3] R. A. Wadsworth and A. R. Lebbie, "What happened to the forests of Sierra Leone?” Land, vol. 8, p. 80, 2019.

[4] S. Spratt, P. Kargbo, P. E. Marfo, E. Ngungoh, and S. R. Suominen, Forest Taxation and REDD+: An Analysis of Potential Impacts in Cameroon, Ghana and Sierra Leone, Institute of Development Studies, Falmer, UK, 2018.

[5] O. Brown and A. Crawford, Conservation and Peace Building in Sierra Leone, International Institute for Sustainable Development (IISD), Winnipeg, Canada, 2000.

[6] M. Bakarr, J. F. Oates, J. Fahr, M. P. E. Parren, M. O. Rodel, and R. Demey, "Guinean forests of West Africa," in Hotspots Revisited: Earth's Biologically Richest and Most Endangered 
Terrestrial Ecoregions, R. A. Mittermeier, P. Robles Gil, M. Hoffman et al., Eds., CEMEX and Conservation International, Washington, DC, USA, 2004.

[7] N. Myers, R. A. Mittermeier, C. G. Mittermeier, G. A. B. da Fonseca, and J. Kent, "Biodiversity hotspots for conservation priorities," Nature, vol. 403, no. 6772, pp. 853-858, 2000.

[8] World Bank, "Sierra Leone biodiversity conservation project," Report No: AB2770, World Bank, Washington, DC, USA, 2010.

[9] A. B. Karim, "Assessment of damage caused to the environment and biodiversity: mining and agriculture," in Proceeding to the National Workshop on the Protection and Rehabilitation of Sierra Leone's Environment, Freetown Sierra Leone: The Way Forward, SLANGO, UNDP and GOSL, Freetown, Sierra Leone, 1996.

[10] FAO/FRA, “Global forest resource assessment," Country Report Sierra Leone. FRA 2010/189, FAO, Rome, Italy, 2010.

[11] FAO/FRA, “Global forest resource assessment 2015," Country Report Sierra Leone, FAO, Rome, Italy, 2015.

[12] R. R. Rodrigues and G. J. Shepherd, "Fatorescondicionantes da vegetaçãociliar," in MatasCiliares: conservação e recuperação, R. R. Rodrigues and H. F. LeitãoFilho, Eds., pp. 101-107, Edusp/Fapesp, São Paulo, Brazil, 2000.

[13] R. J. Naiman and H. Décampus, "The ecology of the interface: riparian zones," Annual Review of Ecological System, vol. 28, pp. 621-658, 1997.

[14] R. D. Barling and I. D. Moore, "Role of buffer strips in management of waterway pollution: a review," Environmental Management, vol. 18, no. 4, pp. 543-558, 1994.

[15] W. G. Hood and R. J. Naiman, "Vulnerability of riparian zones to invasion by exotic vascular plants," Plant Ecology, vol. 148 , no. $1,2000$.

[16] D. U. Hooper, F. S. Chapin, J. J. Ewel et al., "Effects of biodiversity on ecosystem functioning: a consensus of current knowledge," Ecological Monographs, vol. 75, no. 1, pp. 3-35, 2005.

[17] USAID, Nigeria Biodiversity and Tropical Forestry Assessment; Maximizing Agricultural Revenue in Key Enterprises for Targeted Sites (Markets), USAID, Washington, DC, USA, 2008.

[18] K. L. Fetherston, R. J. Naiman, and R. E. Bilby, "Large woody debris, physical process, and riparian forest development in montane river networks of the Pacific Northwest: geomorphology, terrestrial and freshwater systems," Biogeomorphology, Terrestrial and Freshwater Systems, vol. 13, no. 1-4, pp. 133-144, 1995.

[19] R. J. Naiman, H. Decamps, and M. Pollock, "The role of riparian corridors in maintaining regional biodiversity," Ecological Applications, vol. 3, no. 2, pp. 209-212, 1993.

[20] K. L. Cockle and J. S. Richardson, "Do riparian buffer strips mitigate the impacts of clear-cutting on small mammals?" Biological Conservation, vol. 113, no. 1, pp. 113-140, 2003.

[21] S. C. Rottenborn, "Predicting the impacts of urbanization on riparian bird communities," Biological Conservation, vol. 88, no. 3, pp. 289-299, 1999.

[22] R. B. Blair, "Land use and avian species diversity along an urban gradient," Ecological Applications, vol. 6, no. 2, pp. 506-519, 1996.

[23] A. K. Natta, B. Sinsin, and L. J. G. van der Maesen, "Riparian forests and biodiversity conservation in Benin (West Africa)," in Proceedings of a Paper Submitted to the XII World Forestry Congress, Quebec City, Canada, September 2003.

[24] N. Ceperley, F. Montagnini, and A. Natta, "Importance des sites sacrés pour la conservation des forêtsgaleries a centre
Benin," Bois et Forêts Des Tropiques, vol. 303, no. 303, pp. 5-23, 2010.

[25] R. J. Naiman, J. J. Latterell, N. E. Pettit, and J. D. Olden, "Flow variability and the biophysical vitality of river systems," Comptes Rendus Geoscience, vol. 340, no. 9-10, pp. 629-643, 2008.

[26] O. Sambaré, F. Bognounou, R. Wittig, and A. Thiombiano, "Woody species composition, diversity and structure of riparian forests of four watercourses types in Burkina Faso," Journal of Forestry Research, vol. 22, no. 2, pp. 145-158, 2011.

[27] W. Barrella, J. R. M Petrere, W. S. Smith, and L. F. A. Montag, "Asrelações entre as matasciliares, osrios e ospeixes," in MatasCiliares: conservação e recuperação, R. R. Rodrigues and H. d. F. LeitãoFilho, Eds., pp. 187-207, Edusp, São Paulo, Brazil, 2000.

[28] S. R. Biswas and A. U. Mallik, "Disturbance effects on species diversity and functional diversity in riparian and upland plant communities," Ecology, vol. 91, no. 1, pp. 28-35, 2010.

[29] Geomatics International, The Assessment of Vegetation and Land Use Changes in Nigeria between 1976/78 and 1993/95, Prepared for the Forest Management, Evaluation and Coordinating Unit, Nigerian Federal Department of Forestry, under the World Bank Environmental Management Project, Mabushi, Nigeria, 1998.

[30] L. Rocha-Uriartt, D. F. P. Becker, V. Graeff, N. M. Koch, and J. L. Schmitt, "Functional patterns and species diversity of epiphytic vascular spore-producing plants in riparian forests with different vegetation structure from southern Brazil," Plant Ecology and Evolution, vol. 149, no. 3, pp. 261-271, 2016.

[31] N. Hough-Snee, B. B. Roper, and J. M. Wheaton, Multi-scale Drivers of Riparian Vegetation: A Case from the Upper Columbia and Missouri River Basins, Utah State University Spring Runoff, Logan, UT, USA, 2013.

[32] C. S. Meek, D. M. Richardson, and L. Mucina, "A river runs through it: land-use and the composition of vegetation along a riparian corridor in the Cape Floristic Region, South Africa," Biological Conservation, vol. 143, no. 1, pp. 156-164, 2010.

[33] L. V. Reynolds and D. J. Cooper, "Environmental tolerance of an invasive riparian tree and its potential for continued spread in the Southwestern US," Journal of Vegetation Science, vol. 21, pp. 733-743, 2010.

[34] M. McBride, W. C. Hession, and D. M. Rizzo, "Riparian reforestation and channel change: how long does it take?" Geomorphology, vol. 116, no. 3-4, pp. 330-340, 2010.

[35] A.-M. Truscott, S. C. Palmer, C. Soulsby, S. Westaway, and P. E. Hulme, "Consequences of invasion by the alien plant Mimulus guttatus on the species composition and soil properties of riparian plant communities in Scotland," Perspectives in Plant Ecology, Evolution and Systematics, vol. 10, no. 4, pp. 231-240, 2008.

[36] A. Ghermandi, V. Vandenberghe, L. Benedetti, W. Bauwens, and P. A. Vanrolleghem, "Model-based assessment of shading effect by riparian vegetation on river water quality," Ecological Engineering, vol. 35, no. 1, pp. 92-104, 2009.

[37] D. M. Richardson, P. M. Holmes, K. J. Esler et al., "Riparian vegetation: degradation, alien plant invasions, and restoration prospects," Diversity and Distributions, vol. 13, no. 1, pp. 126-139, 2007.

[38] N. Prins, P. M. Holmes, and D. M. Richardson, “A reference framework for the restoration of Criparian vegetation in the Western Cape, South Africa, degraded by invasive Australian Acacias," South African Journal Botany, vol. 70, pp. 767-776, 2005. 
[39] M. L. Burton, L. J. Samuelson, and S. Pan, "Riparian woody plant diversity and forest structure along an urban-rural gradient," Urban Ecosystems, vol. 8, no. 1, pp. 93-106, 2005.

[40] R. A. Obedzinski, C. G. Shaw, and D. G. Neary, "Declining woody vegetation in riparian ecosystems of the western United States," Western Journal of Applied Forestry, vol. 16, no. 4, pp. 169-181, 2001.

[41] A. H. Winward, Monitoring the Vegetation Resources in Riparian Areas, US Department of Agriculture, Forest Service, Rocky Mountain Research Station, Ogden, UT, USA, 2000.

[42] M. Fayiah, M. K. Swarray, G. Otesile, and B. Chen, "Comparative study of the regeneration potential of kasewe and Taia riverine forests, Moyamba District, Sierra Leone," in Proceedings of the 40th annual Conference of Forestry Association of Nigeria (FAN), Lagos, Nigeria, March 2018.

[43] T. C. Whitmore, An Introduction to Tropical Rain Forest, Oxford University Press, New York, NY, USA, 2nd edition, 1998.

[44] S. S. Leone, Population and Housing Census, Government of the Republic of Sierra Leone, University Of Sierra Leone, Tower Hills, Sierra Leone, 2004.

[45] A. K. Mishra, S. K. Behera, K. Singh, R. M. Mishra, L. B. Chaudhary, and B. Singh, "Effect of abiotic factors on understory community structures in moist deciduous forests of Northern India," Forest Science and Practice, vol. 15, no. 4, pp. 261-273, 2013.

[46] P. S. Savill and J. E. D. Fox, The Trees of Sierra Leon, Government Printing Press, Freetown, Sierra Leone, 1967.

[47] R. Mishra, Ecology Workbook, Oxford and IBH Publishing Co. Ltd., New Delhi, India, 2013.

[48] P. Michael, Ecological Methods for Field and Laboratory Investigation, Tata McGraw Hill Publishing Co. Ltd., New Delhi, India, 1990.

[49] S. M. Philip, Measuring Trees and Forests. A Textbook Written for a Student in Africa, UDSM, Division of Forestry, Dar es Salaam, Tanzania, 1983.

[50] C. E. Shannon and W. Wiener, The Mathematical Theory of Communication, University of Juionis Press, Urbana, IL, USA, 1963.

[51] M. Kent and P. Coker, Vegetation Description and Analysis, a Practical Approach, p. 363, Bell-Heaven Press, London, UK, 1992.

[52] P. Gaines, C. T. Woodard, and J. R. Carlson, "An enhancer trap line identifies the Drosophila homolog of the L37a ribosomal protein," Gene, vol. 239, no. 1, pp. 137-143, 1999.

[53] E. H. Simpson, "Measurement of diversity," Nature, vol. 163, no. 4148 , p. 688, 1949.

[54] A. E. Magurran, Ecological Diversity and its Measurement, Princeton University Press, Princeton, NJ, USA, 1988.

[55] E. C. Pielon, Ecological Diversity, John Wiley \& Sons, Hoboken, NJ, USA, 1975.

[56] FORMECU, National Forest Resource Survey, Training Manual, Federal Department of Forestry, Abuja, Nigeria, 1997.

[57] M. Fayiah and E. Bendu, "Plant species diversity at kasewe forest reserve," in Proceedings of the 39th Annual Conference of the Forestry Association of Nigeria, Minna, Nigeria, November 2016.

[58] A. E. Magurran, Measuring Biological Diversity, Blackwell Science, Ltd., Oxford, UK, 2004.

[59] C. Mligo, "Diversity and distribution pattern of riparian plant species in the Wami River system, Tanzania," Journal of Plant Ecology, vol. 10, no. 2, pp. 259-270, 2017.

[60] P. Gomez-Roxas, R. D. Boniao, E. M. Burton, A. GorospeVillarino, and S. S. Nacua, Community-Based Inventory and
Assessment of Riverine and Riparian Ecosystems in the Northeastern Part of Mt. Malindang, Misamis Occidental. Biodiversity Research Programme (BRP) for Development in Mindanao, Focus on Mt. Malindang and Environs, SEAMEO, SEARCA, Los Baños, Philippines, 2005.

[61] R. Pither and M. Kellman, "Tree species diversity in small, tropical riparian forest fragments in Belize, Central America," Biodiversity and Conservation, vol. 11, no. 9, pp. 1623-1636, 2002.

[62] H. Pereki, K. Wala, T. Thiel-Clemen et al., "Woody species diversity and important value indices in dense dry forests in Abdoulaye Wildlife Reserve (Togo, West Africa)," International Journal of Biodiversity and Conservation, vol. 5, no. 6, pp. 358-366, 2013.

[63] M. Appiah, "Tree population inventory, diversity and degradation analysis of a tropical dry deciduous forest in Afram Plains, Ghana," Forest Ecology and Management, vol. 295, pp. 145-154, 2013.

[64] J. E. Rad, M. Manthey, and A. Mataji, "Comparison of plant species diversity with different plant communities in deciduous forests," International Journal of Environmental Science \& Technology, vol. 6, no. 3, pp. 389-394, 2009.

[65] A. Reynal-Roques, La Botanique Redecouverte, Humensis, Paris, France, 1994.

[66] T. D. Houehanou, R. L. Glèlè Kakaï, A. E. Assogbadjo et al., "Change in the woody floristic composition, diversity and structure from protected to unprotected savannahs in Pendjari Biosphere Reserve (Benin, West Africa)," African Journal of Ecology, vol. 51, no. 2, pp. 358-365, 2012.

[67] H. I. Aigbe, T. O. Adeyemo, and B. A. Oyebade, "Assessment of tree biodiversity of two tropical rainforest in cross river state, Nigeria," International Journal of Scientific \& Engineering Research, vol. 66 pages, 2015.

[68] T. Sahoo, P. C. Panda, and L. Acharya, "Structure, composition and diversity of tree species in tropical moist deciduous forests of Eastern India: a case study of Nayagarh Forest Division, Odisha," Journal of Forest Research, vol. 28, pp. 12-19, 2017.

[69] I. Kargbo, "Volume estimation of merchantable trees of Kambui North forest Kenema District Sierra Leone," A Dissertation submitted to the School of Agriculture in Partial Fulfillment for the Award of Higher Diploma in Forestry, School of Forestry and Horticulture, Njala University, Moyamba, Sierra Leone, 2009.

[70] A. Bangura, "Comparative assessment of two Vegetation within Njama community, Moyamba District," A Dissertation Submitted to the Department of Forestry, School of Natural Resources Management, Njala University, Freetown, Sierra Leone, 2013.

[71] J. Castaño-Santamaría, F. Crecente-Campo, J. L. FernándezMartínez, M. Barrio-Anta, and J. R. Obeso, "Tree height prediction approaches for uneven-aged beech forests in northwestern Spain," Forest Ecology and Management, vol. 307, pp. 63-73, 2013.

[72] S. Singh, "Ecological studies and assessment of regeneration potential of different stands of Jatropha curcas Linn. At different localities in Uttarakhand," Doctoral dissertation, Hemwati Nandan Bhauguna Garhwal University Srinagar (Garhwal), Uttarakhand. India, 2013.

[73] F. A. A. M. N. Soares, E. L. Flôres, C. D. Cabacinha, G. A. Carrijo, and A. C. P. Veiga, "Recursive diameter prediction and volume calculation of eucalyptus trees using Multilayer Perceptron Networks," Computers and Electronics in Agriculture, vol. 78, no. 1, pp. 19-27, 2011. 
[74] L. J. Moores, B. Pittman, and G. Kitchen, "Forest ecological classification and mapping: their application for ecosystem management in Newfoundland," Global to Local: Ecological Land Classification, vol. 39, no. 1-3, pp. 571-577, 1996.

[75] A. Diamantopoulou, "Tree-bole volume estimation on standing pine trees using cascade correlation artificial Neural Network models," Agricultural Engineering International: The CIGR Ejournal, vol. 8, 2006.

[76] W. Suzuki, K. Osumi, T. Masaki, K. Takahashi, H. Daimaru, and K. Hoshizaki, "Disturbance regimes and community structures of a riparian and an adjacent terrace stand in the Kanumazawa Riparian Research Forest, Northern Japan," Forest Ecology and Management, vol. 157, no. 1-3, pp. 285301, 2002.

[77] B. G. Wilson and E. T. F. Whitkowiski, "The seed bank, bark thickness and changes in age and size structure (1978-1999) of African savanna tree Burkea," Plant Ecology, vol. 167, no. 1, pp. 151-162, 2003.

[78] J. Botha, E. T. F. Witkowski, and C. M. Shackleton, "The impact of commercial harvesting on Warburgia salutaris ("pepper-bark tree") in Mpumalanga, South Africa," Biodiversity and Conservation, vol. 13, no. 9, pp. 1675-1698, 2004.

[79] K. P. McLaren, M. A. McDonald, J. B. Hall, and J. R. Healey, "Predicting species response to disturbance from size class distributions of adults and saplings in a Jamaican tropical dry forest," Plant Ecology, vol. 181, no. 1, pp. 69-84, 2005.

[80] E. N. Mwavu and E. T. F. Witkowski, "Population structure and regeneration of multiple-use tree species in a semi-deciduous African tropical rainforest: implications for primate conservation," Forest Ecology and Management, vol. 258, no. 5, pp. 840-849, 2009.

[81] J. Obiri, M. Lawes, and M. Mukolwe, "The dynamics and sustainable use of high-value tree species of the coastal Pondoland forests of the Eastern Cape Province, South Africa," Forest Ecology and Management, vol. 166, no. 1-3, pp. 131-148, 2002.

[82] L. L. Osborne and D. A. Kovacic, "Riparian vegetated buffer strips in water-quality restoration and stream management," Freshwater Biology, vol. 29, no. 2, pp. 243-258, 1993.

[83] B. W. Sweeney, "Effects of streamside vegetation on macro invertebrate communities of White Clay Creek in eastern North America," Proceedings of the Academy of Natural Sciences of Philadelphia, vol. 144, pp. 291-340, 1993.

[84] USEPA, Methods for Evaluating Wetland Condition: Vegetation-Based Indicators of Wetland Nutrient Enrichment, USEPA, Washington, DC, USA, 2002.

[85] G. Martín, L. Sirombraa, and M. Mesab, "A method for assessing the ecological quality of riparian forests in subtropical Andean streams," QBRy Index Ecological Indicators, vol. 20, pp. 324-331, 2012.

[86] M. Fayiah, S. Dong, and S. Singh, "Status and challenges of wood biomass as the principal energy in Sierra Leone," International Journal of Biomass \& Renewables, vol. 7, no. 2, pp. 1-11, 2019.

[87] USDA Forest Service, Overview of the Western Peninsular Forest Reserve (WPFRP), USDA Forest Service, Washington, DC, USA, 2000.

[88] A. K. Natta, Ecological assessment of riparian forests in Benin: phytodiversity, phytosociology and spatial distribution of trees species, Ph.D. thesis, Wageningen University, Wageningen, The Netherlands, 2003. 